\title{
Giant Strides
}

T The last year has seen an explosion of interest in the environment, global climate change, and ecological restoration in the United States and around the world. It has also been an auspicious time for the Society for Ecological Restoration International (SER). SER has matured as an organization and has gained strength as an important voice dealing with the world's environmental woes. I would like to take this opportunity to share some of the highlights.

In March of 2007 after years of preparation, SER's Executive Director M.K. Lefevour and Project Director Sasha Alexander launched the much anticipated Global Restoration Network (GRN) at www.globalrestorationnetwork.org. The GRN is the world's first comprehensive online resource on ecological restoration practice, research, and expertise.

Also in March of this year, following a three-day retreat in Jacksonville, Florida, the SER Board and colleagues developed a five-year strategic plan for the society. One of the important products of the retreat was consensus that SER should engage in the world of policy, and advocate directly for ecological restoration. This point was strongly advocated for by SER past Chair (1995-1997) Nik Lopoukhine, now head of the World Commission on Protection Areas.

This past August SER held a joint meeting with the Ecological Society of America (ESA) attended by about 4,500 people in San Jose, California. It was the largest meeting ever held by either group. The theme was "Ecology-based Restoration in a Changing World." Literally thousands of papers and posters were presented, many of these on ecological restoration research. SER also released a position statement on the role of ecological restoration in mitigating global climate change. The statement was subsequently endorsed by the ESA Board of Governors. We held a press conference at the joint meeting to release the statement, and subsequent interest has been truly phenomenal. Excerpts from our position statement and press release have made it into dozens of media outlets and blogs.

The meeting featured two symposia-one on key concepts and research questions in restoration ecology and one on setting goals and targets for the restoration and management of large-scale ecosystems. Both of these events provided

Ecological Restoration Vol. 25, No. 4, 2007

ISSN 1522-4740 E-ISSN 1543-4079

C 2007 by the Board of Regents of the University of Wisconsin System. opportunities for SER and ESA members to interact on key topics such as how we restore ecosystems in the context of global change, and how much emphasis should be placed on historical fidelity in the design and implementation of restoration projects. Organizational business was also conducted, including SER board approval of the strategic plan, the passing of the position of SER Chair of the Board from Keith Bowers to me, and the presentation of several key awards: John Rieger Award (Bill Halvorson); Theodore Sperry Award (Edward Redente); Communications Award (James Aronson); and Excellence in Leadership Award (Keith Bowers). It also provided me an opportunity to meet with Mrill Ingram, the editor of Ecological Restoration, to discuss our long-term collaboration.

In the closing session of the conference I encouraged SER and ESA to continue working together to further both the science and the practice of ecological restoration, and to insure that restoration happens across landscapes, not just in the United States, but around the world. I also spoke about the tension between restoration science and practice, and how SER provides a framework whereby practitioners (like me) and scientists can share information on a peer-to-peer basis. SER does not perceive practitioners as receivers of information or perceive scientists as givers of information. We share knowledge about restoration in an environment of mutual respect. A gap remains between the practical and research oriented ends of the field, however, and we all need to work to fix this critical problem. It is true that many more scientists are becoming restoration practitioners in response to the global environmental crisis-not just agency and NGO scientists, but also academic scientists - and this is to be applauded. I encouraged scientists to view all restoration projects as opportunities for research, and to view their practitioner partners as scientific colleagues. Gaining knowledge alone is no longer enough.

This brings me to you, the readers of Ecological Restoration. It is also not enough anymore to practice ecological restoration in isolation. I am sure Mrill Ingram would join me in saying now more than ever we need you all to sit down, write, and share your information with the world.

Many thanks,

George Gann, Chair

Society for Ecological Restoration International 